\title{
Brain stroke computed tomography images analysis using image processing: A review
}

\author{
Nur Hasanah Ali ${ }^{1}$, Abdul Rahim Abdullah ${ }^{2}$, Norhashimah Mohd Saad ${ }^{3}$, Ahmad Sobri Muda ${ }^{4}$, \\ Tole Sutikno ${ }^{5}$, Mohd Hatta Jopri' \\ ${ }^{1}$ Faculty of Engineering and Technology, Multimedia University, Melaka, Malaysia \\ ${ }^{2}$ Faculty of Electrical Engineering, Universiti Teknikal Malaysia Melaka, Malaysia \\ ${ }^{3,6}$ Faculty of Electrical \& Electronic Engineering Technology, Universiti Teknikal Malaysia Melaka, Malaysia \\ ${ }^{4}$ Department of Imaging, Faculty of Medicine and Health Sciences, Universiti Putra Malaysia, Selangor, Malaysia \\ ${ }^{5}$ Department of Electrical Engineering, Universitas Ahmad Dahlan, Yogyakarta, Indonesia
}

\begin{tabular}{l} 
Article Info \\
\hline Article history: \\
Received May 21, 2021 \\
Revised Aug 27, 2021 \\
Accepted Sep 12, 2021 \\
\hline
\end{tabular}

\section{Keywords:}

Brain stroke

Computed tomography

CT scan

Medical imaging

Segmentation

\begin{abstract}
Stroke is the second-leading cause of death globally; therefore, it needs immediate treatment to prevent the brain from damage. Neuroimaging technique for stroke detection such as computed tomography (CT) has been widely used for emergency setting that can provide precise information on an obvious difference between white and gray matter. CT is the comprehensively utilized medical imaging technology for bone, soft tissue, and blood vessels imaging. A fully automatic segmentation became a significant contribution to help neuroradiologists achieve fast and accurate interpretation based on the region of interest (ROI). This review paper aims to identify, critically appraise, and summarize the evidence of the relevant studies needed by researchers. Systematic literature review (SLR) is the most efficient way to obtain reliable and valid conclusions as well as to reduce mistakes. Throughout the entire review process, it has been observed that the segmentation techniques such as fuzzy C-mean, thresholding, region growing, $\mathrm{k}$-means, and watershed segmentation techniques were regularly used by researchers to segment CT scan images. This review is also impactful in identifying the best automated segmentation technique to evaluate brain stroke and is expected to contribute new information in the area of stroke research.
\end{abstract}

This is an open access article under the CC BY-SA license.

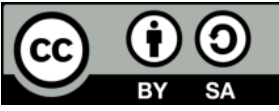

\section{Corresponding Author:}

Nur Hasanah Ali

Faculty of Engineering and Technology

Multimedia University

Melaka, Malaysia

Email: hasanah.ali@mmu.edu.my

\section{INTRODUCTION}

Brain is a hugely complex and fascinating organ in the human body composing of cerebrum, cerebellum, and brainstem that being protected by the skull [1]. This organ is composed of a number of support networks and billions of connected nerve cells. The brain is having complex space-time patterns characteristic. That is the reason the brain is considered the most complex system, where the degree of correspondence between structural and functional connectivity depends on time scales and spatial resolution [2]. The brain has the ability to control intelligence, creativity, emotion, and memory. The brain is also divided into parietal, frontal, temporal and occipital lobes which interconnect with the body through the spinal cord as well as twelve pairs of cranial vessels through blood circulation as shown in Figure 1. The cranial vessels for smell and vision originate in the cerebrum. Therefore, good blood circulation in the vessels 
is important to avoid neuronal damage and subsequent neurological deficits that will lead to cell death [3], [4].

Stroke is the world's second-leading cause of mortality, according to data [5]-[7]. It needs immediate treatment to minimize the risk of death or serious long-term disability. It is a medical condition where a blood vessel bursts or is blocked. As a result, blood flow to a part of the brain is reduced. As shown in Figure 2, stroke can be categorized into hemorrhagic and ischemic stroke. An ischemic stroke happens when there is a blockage in the blood vessel that leads to abrupt occlusion of a cerebral artery while hemorrhagic stroke (brain bleed) occurs when a blood vessel breaks [8]-[11]. When a stroke happens, in each minute, millions of nerve cells and billions of synapses die [12]-[14]. This problem amplifies the notion as "time is brain". Despite a critical need, there is no established automatic system for stroke, although several automated systems in other fields, including mammography and chest, are among others [15]-[18]. Furthermore, based on studies on computed-aided diagnosis (CAD) systems and technology, it shows that the diagnostic accuracy of radiologists can be improved by using CAD [19]-[29].

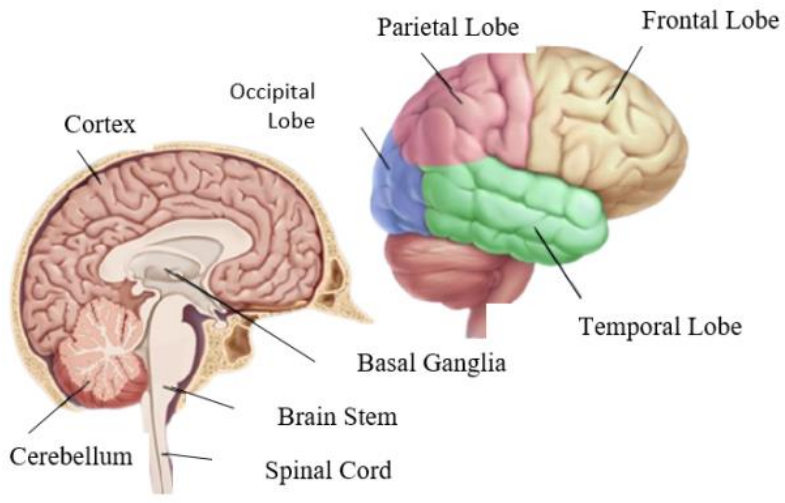

Figure 1. Anatomy of human brain

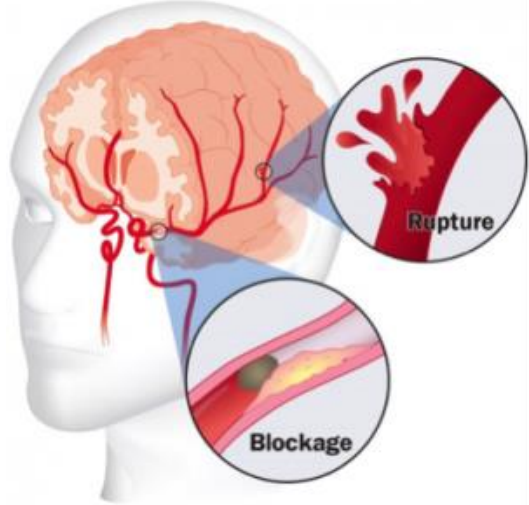

Figure 2. Types of stroke

Computed tomography (CT) scan is one imaging modality that uses multiple X-ray sources and detectors to determine emergency life-threatening neurocranial pathology [30]-[38]. There are two parts inside the CT scanner: a sensor and an X-ray tube to rotate the frame. X-ray beam is generated when the rotating frame rotates the X-ray tube and detector around the patient. One image will be obtained each time the X-ray tube and detector make one complete cycle. The volume data set can then be computer reconstructed to provide three-dimensional (3D) images of complex structures [39]. In cases of trauma and emergent situations, CT performs better as compared to other imaging modalities. It offers better bone detail and has a high sensitivity for acute hemorrhage. CT has become a critical tool in medical imaging to supplement X-rays, medical ultrasonography (USG), and MR imaging. Despite being more cost-effective [40], CT is preferred in the early screening of diseases, especially for patients with a high risk of stroke. CT scans are typically used to detect brain infarct, bleeding, and skull fracture in patients with a better scan time [41]. The image of a CT scan is shown in Figure 3. However, CT has the disadvantages of exposure to ionizing radiation and the potential to misdiagnose certain diseases [42].

In this paper, a review of brain stroke CT images according to the segmentation technique used is presented. Segmentation techniques, includes threshold, fuzzy C-means, region growing, watershed, and kmeans segmentation are proposed. Furthermore, as to the best of our knowledge, this paper is the first attempt to review the most relevant brain stroke structure segmentation. As for literature, the primary databases: Scopus, IEEE Xplore, PubMed, and Scholar using systematic literature review (SLR) are searched. The technique is the most efficient way to review papers in which the results are based on a qualitative level instead of a quantitative one. The key three search strategy concepts are mainly brain stroke, CT imaging modality, and segmentation technique. Initially, the works that were out of the scope of this review, such as various brain infarct segmentation techniques, other image modalities, or different segmentation approaches are omitted, while keeping only the works that strictly proposed on segmentation for brain stroke in CT image modality. To retrieve other relevant research work, the reference lists of the selected publications are surveyed, and those related research works to the objective are included. 


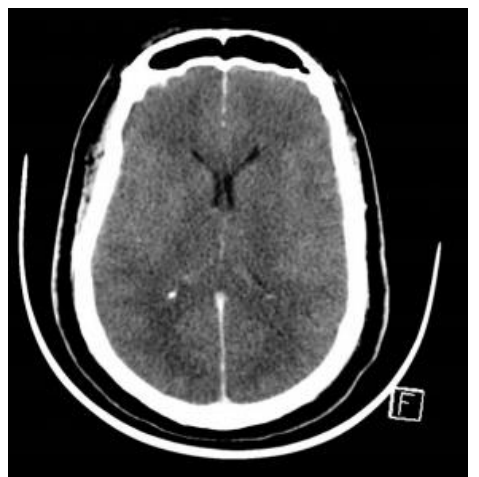

Figure 3. CT image [43]

\section{SEGMENTATION TECHNIQUES}

Signal processing and machine learning (ML) techniques have been successfully applied to several fields [44]-[62]. Furthermore, the digital signal processing (DSP) technique is always applied to extract the features of the signals and use it with related MLs [63]-[68]. In medical imaging applications, machine learning techniques suffer from several limitations due to the variety of possible shapes, locations, and intensity inhomogeneity [69]-[75]. These techniques relied heavily on manual functions developed by doctors and neuroradiologists in the field [76]. Every patient might have different observed data, and the interpretation of the data depends on the experience of those skilled in the art, this can lead to errors within and between observers [77]. Segmentation ensues by dividing digital images into multiple segments into nonoverlapped areas that share characteristics such as shape, intensity, or texture to locate and identify objects and boundaries in an image [18], [78]-[89]. In further parts of this paper, the various techniques of segmentation are discussed and compared.

\subsection{Threshold based segmentation}

Ali et al. [90] discussed that threshold based technique is the simplest and computationally efficient approach to segment brain stroke because only intensity values need to be considered and rejects other pixels with values less than the threshold. This process is repeated twice, and the median filter is applied to obtain a smooth image and less noise.

Badriyah et al. [91] discussed the concept of stroke segmentation using the thresholding technique. They found out that this technique needs optimization to remove the brain skull image so that the cerebral scalp is invisible and sharpens the edges of the brain. The best output can be obtained by combining the Binary and Otsu thresholding techniques.

Flottmann et al. [92] differentiated between threshold-free probabilistic and traditional threshold techniques. The traditional technique exhibited more error on infarct volumes, whereas the probabilistic technique gave consistent prediction mean infarct volumes nearer to the actual volumes value and with higher accuracy. The comparison of the original image and after been segmented using threshold segmentation technique as shown in Figure 4.
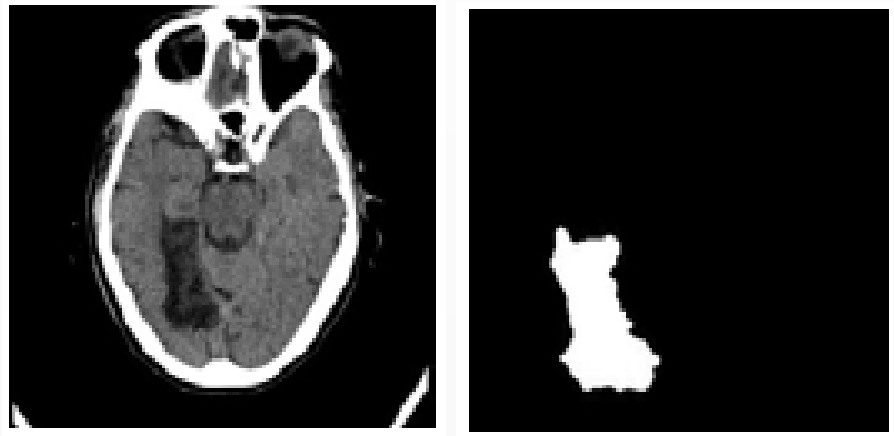

Figure 4. Original and segmented image using threshold technique [26]

Int J Artif Intell, Vol. 10, No. 4, December 2021: 1048 - 1059 


\subsection{Fuzzy c-means (FCM)}

Kumar et al. [93] proposed a newly improved FCM technique that combined skull removal, automatic selection of cluster, FCM, thresholding and edge-based active contour techniques. The proposed technique has higher accuracy as compared to FCM clustering and manual fuzzy based active contour. Kaur et al. [12] estimated that FCM could cater vague and ambiguous CT images. In [12] concluded that the extended FCM (EFCM) has the highest efficiency compared to other image segmentation technique.

Bhadauria and Dewal [94] proposed a technique that combines the FCM technique with the region-based active contour technique for detecting haemorrhage with accuracy and minimum timeframe. The result showed that the proposed technique achieved the highest average dice coefficients, which is 0.8748 , compared with conventional FCM and region based technique. In addition, this technique is better suited for CT images that have intensity inhomogeneities. This is due to the intensity information in the local regions to assist the contour towards the hemorrhage boundaries for higher accuracy and robustness [95]. Figure 5 shows the comparison of the original image and after been segmented using FCM segmentation technique.
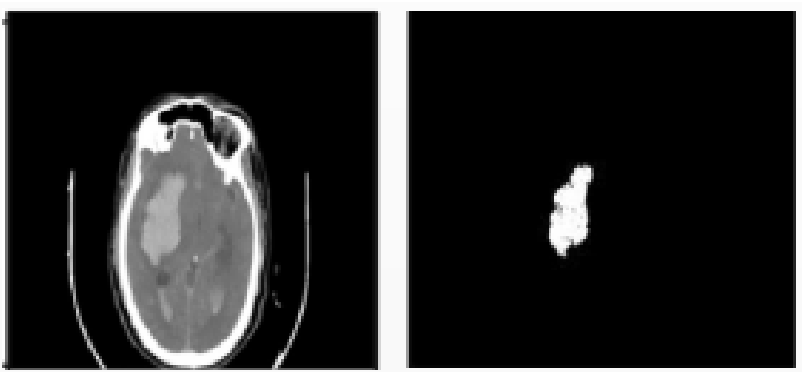

Figure 5. Original and segmented image using FCM technique [21]

\subsection{Region growing segmentation}

Biratu et al. [96] and Ali et al. [97] described the technique that can segment based on the similar pixel at the ROI and divides CT image into several areas with homogeneity properties. This technique's performance highly relies on the initial seed point selection and the similarity measure used between neighboring pixels. Matesin et al. [98] proposed a rule-based technique to segment CT images by the identification at the head symmetry axis based on moments. Other than that, to recognize various areas with rule-based region labeling and uniform brightness, seeded region growing (SRG) is used. SRG has the advantages of being fast, robust, and easy to tune the parameters once seeds are placed. Furthermore, this technique abled to follow the natural boundaries of CT images closely.

Bhadauria and Dewal [94] examined a combination of region growing technique with fuzzy c-mean technique, which gives a robust and accurate detection of hemorrhagic regions to be compared against experts' manual segmentations. Gupta and Mittal [99] and Saini and Banga [100] presented that region growing segmentation technique has the advantage of generating better ROI for brain stroke segmentation. However, Gupta and Mittal [99] proposed homotopic region-growing technique to reduce noise sensitivity and region extraction disconnection.

\subsection{Watershed segmentation}

Watershed segmentation is a technique based on region segmentation. This technique starts with origins in mathematical morphology [101]. For this segmentation technique, the topological surface, mainly the 2D grey-scale image represents each pixel corresponds to a "position" whereas the intensity refers the "altitude" [102].

Ajam et al. [103] proposed the marker controlled watershed technique that can reduce the oversegmentation problem due to noise. The over-segmentation usually occurred when the standard watershed technique is used. The newly proposed technique spot the foreground images by using morphological operations which are "opening-by-reconstruction" and "closing-by-reconstruction" that creates maxima contrast for each object.

Arasan et al. [104] discussed the efficacy of watershed segmentation technique to detect gray scale and accurately multiple regions simultaneously. Other than that, the proposed technique does not require contour joining, as it produces complete contour of the segments. Nivedhitha and Sankar [105] proposed "hemorrhage detection system using watershed segmentation" which contributed for detecting CT images

Brain stroke computed tomography images analysis using image processing: A review (Nur Hasanah Ali) 
with and without haemorrhage. A precise segmentation and classification of haemorrhage stroke regions are essential for correct detection and diagnosis. Features are extracted using watershed segmentation to get a smooth image and able to cater to multi-classification problems. Experiments have been conducted to achieve the promising with an accuracy of $97 \%$ after segmentation. Figure 6 illustrates the comparison of the original and segmented image using watershed segmentation technique.

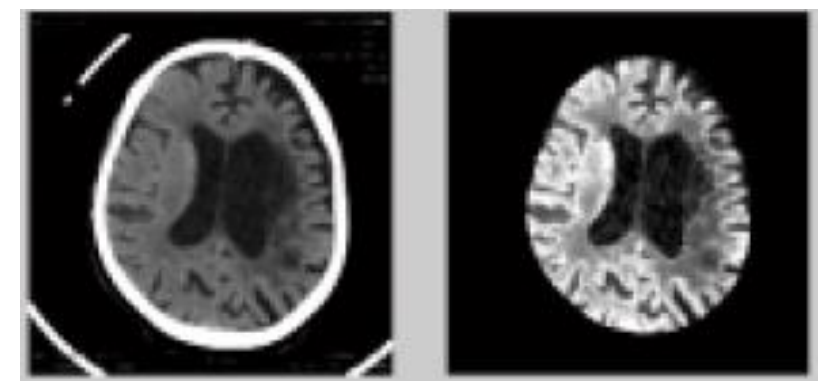

Figure 6. Original and segmented image using watershed technique [101]

\subsection{K-means segmentation}

K-means segmentation techniques are based on partition clustering segmentation techniques [106] that are more suitable and practical for biomedical images such as CT images [36]. According to Vankayalapati et al. [107], for a large number of data, K-means offers high computational time. Purohit and Joshi [108] proposed a new technique for producing the cluster centre without sacrificing implementation time. They also stated the initialization of $\mathrm{k}$ value plays a vital role in producing a good result in each cluster as it generates stability and reduces the mean square error. According to the studies, it shows the accuracy result is more for dense datasets as compared with sparse datasets.

Lee et al. [109] proposed a segmentation technique using EM clustering and k-means. The paper uses several segmentation techniques to divide the brain into 3 clusters: cerebrospinal fluid, abnormal regions, as well as brain matter. The techniques that have been used in their experiment are decision tree, $\mathrm{k}$-means and expectation-maximization (EM) technique.

Rajini and Bhavani [110] proposed a k-means segmentation technique to detect ischemic stroke in CT scan images, texture features and outlining midline shift algorithm. They concluded that their technique could generate precise quantitative results suitable for clinical use. It has been proved by the result of the average precision, average overlap metric, and average recall are $0.99,0.98$ and 0.98 , respectively.

\section{RESULTS}

Various techniques are used for brain stroke segmentation using CT scan even though there is a lack of existing studies and research work in databases for evaluation. Comparison summary of the above segmentation techniques is shown in Table 1. Furthermore, based on this review, research work on the segmentation using magnetic resonance imaging (MRI) modality is relatively routine compared to CT imaging modality [111]. All the segmentation techniques purposed is to achieve an efficient and precise system.

Table 1. Comparison of segmentation techniques

\begin{tabular}{|c|c|c|c|}
\hline Technique & Characteristics & Pros & Cons \\
\hline Threshold & Based on the histogram analysis [112] & $\begin{array}{l}\text { Simplest technique, No need for previous } \\
\text { information [91] }\end{array}$ & $\begin{array}{l}\text { Not suitable when ROI and } \\
\text { the unwanted area has } \\
\text { similar intensity [113] }\end{array}$ \\
\hline Region & Selection of initial seed point and & Capable of noise resistance, applicable & Manual selection of \\
\hline Growing & examine neighboring pixels [115] & $\begin{array}{l}\text { when it is easy to identify similarity } \\
\text { criteria [116] }\end{array}$ & $\begin{array}{l}\text { homogeneity criterion } \\
\text { [117] }\end{array}$ \\
\hline K-means & $\begin{array}{l}\text { Divide into k clusters to define k- } \\
\text { centroid value of each cluster [107] }\end{array}$ & $\begin{array}{l}\text { Simple and suitable for large data sets } \\
\text { [110] }\end{array}$ & $\begin{array}{l}\text { Clustering data of varying } \\
\text { sizes and density [120] }\end{array}$ \\
\hline
\end{tabular}

Int J Artif Intell, Vol. 10, No. 4, December 2021: 1048 - 1059 
The clustering technique is mostly used for segmentation process. K-means has the advantage of less computational time as compared to fuzzy c-means [121]. Fuzzy c-means abled to separate different tissue types using a small number of the cluster [93], but K-means uses many clusters for different tissue types [120]. Fuzzy c-means detect abnormalities more accurately than k-means by keeping more information from the original image [122]. Even though computer-aided detection/diagnosis (CAD) can significantly impact automating the image processing and analysis process, it will never replace doctors and radiologists.

\section{CONCLUSION}

This paper has presented a systematic literature review abaout brain stroke computed tomography images analysis using image processing. This review was aimed to identify, critically appraise, and summarize the brain stroke segmentation using CT scan. Throughout the entire review, segmentation method such as thresholding, FCM, region growing, k-means, and watershed segmentation techniques have been deeply observed. All the segmentation techniques are purposed to achieve an efficient and precise system. It is easy to determine infarct with maximum accuracy in a shorter time. From the review, the clustering technique is mostly used for segmentation process. Both k-means as well as fuzzy c-means clustering shows an approximately same result, but k-means has the advantage of less computational time, and fuzzy c-means is superior to separate different tissue types. Fuzzy c-means is better to detect abnormalities than k-means, even though computer-aided detection/diagnosis (CAD) can significantly impact automating the image processing and analysis process.

\section{ACKNOWLEDGEMENTS}

The authors would like to thanks the Universiti Teknikal Malaysia Melaka (UTeM), Faculty of Electrical and Electronic Engineering Technology (FTKEE) and Faculty of Electrical Engineering (FKE), Advance Digital Signal Processing (ADSP) Lab, Centre of Robotic and Industrial Automation (CeRIA) and Ministry of Higher Education (MOHE), Malaysia that supported this research under project FRGS/1/2020/FTKEE CERIA/F00428.

\section{REFERENCES}

[1] L. Kurtaj, V. Shatri, and I. Limani, "Cerebellar model controller with new model of granule cell-golgi cell building blocks and two-phase learning acquires multitude of generalization capabilities in controlling robot joint without exponential growth in complexity," Int. J. Electr. Comput. Eng., vol. 8, no. 6, pp. 4292-4309, 2018, doi: 10.11591/ijece.v8i6.pp4292-4309.

[2] K. Batista-García-Ramó and C. I. Fernández-Verdecia, "What we know about the brain structure-function relationship,” Behav. Sci. (Basel)., vol. 8, no. 4, 2018, doi: 10.3390/bs8040039.

[3] D. Kuriakose and Z. Xiao, "Pathophysiology and treatment of stroke: Present status and future perspectives," Int. J. Mol. Sci., vol. 21, no. 20, pp. 1-24, 2020, doi: 10.3390/ijms21207609.

[4] T. R. Stella Mary and S. Sebastian, "Predicting heart ailment in patients with varying number of features using data mining techniques," Int. J. Electr. Comput. Eng., vol. 9, no. 4, pp. 2675-2681, 2019, doi: 10.11591/ijece.v9i4.pp2675-2681.

[5] Z. Rustam, Arfiani, and J. Pandelaki, "Cerebral infarction classification using multiple support vector machine with information gain feature selection," Bull. Electr. Eng. Informatics, vol. 9, no. 4, pp. 1578-1584, 2020, doi: 10.11591/eei.v9i4.1997.

[6] S. B. Kutty, R. W. O. K. Rahmat, S. S. Kassim, H. Madzin, and H. Hamdan, "An algorithm to measure unsymmetrical circle shape of intravascular ultrasound image using image processing techniques," Bull. Electr. Eng. Informatics, vol. 10, no. 1, pp. 508-515, 2021, doi: 10.11591/eei.v10i1.2694.

[7] S. Krishnan, P. Magalingam, and R. Ibrahim, "Hybrid deep learning model using recurrent neural network and gated recurrent unit for heart disease prediction," Int. J. Electr. Comput. Eng., vol. 11, no. 6, pp. 5467-5476, 2021, doi: 10.11591/ijece.v11i6.pp5467-5476.

[8] M. S. Phipps and C. A. Cronin, "Management of acute ischemic stroke," BMJ, vol. 368, 2020, doi: 10.1136/bmj.16983.

[9] E. C. Djamal, R. I. Ramadhan, M. I. Mandasari, and D. Djajasasmita, "Identification of post-stroke eeg signal using wavelet and convolutional neural networks," Bull. Electr. Eng. Informatics, vol. 9, no. 5, pp. 1890-1898, 2020, doi: 10.11591/eei.v9i5.2005.

[10] P. Parmar, "Stroke: Classification and diagnosis," Clin. Pharm., vol. 10, no. 1, 2018, doi: 10.1211/CP.2018.20204150.

[11] K. I. Ahmed, M. H. Habaebi, and M. D. Islam, "Smartphone aided real-time blood vein detection system," Bull. Electr. Eng. Informatics, vol. 8, no. 3, pp. 1096-1107, 2019, doi: 10.11591/eei.v8i3.1514.

[12] P. Kaur, P. Sharma, and A. Palmia, "Fuzzy clustering-based image segmentation techniques used to segment magnetic resonance imaging/computed tomography scan brain tissues: Comparative analysis," Int. J. Imaging Syst. Technol., vol. 30, no. 4, pp. 1294-1323, 2020, doi: 10.1002/ima.22439. 
[13] H. Roopa and T. Asha, "Feature extraction of chest X-ray images and analysis using PCA and kPCA," Int. J. Electr. Comput. Eng., vol. 8, no. 5, pp. 3392-3398, 2018, doi: 10.11591/ijece.v8i5.pp3392-3398.

[14] M. Rmili, A. El Moutaouakkil, M. M. Saleck, M. Bouchaib, F. Adnani, and E. M. E. Aroussi, "A new approach to the detection of mammogram boundary," Int. J. Electr. Comput. Eng., vol. 8, no. 5, pp. 3587-3593, 2018, doi: 10.11591/ijece.v8i5.pp3587-3593.

[15] S. Uyun and L. Choridah, "Feature selection mammogram based on breast cancer mining," Int. J. Electr. Comput. Eng., vol. 8, no. 1, pp. 60-69, 2018, doi: 10.11591/ijece.v8i1.pp60-69.

[16] K. Slimani, M. Kas, Y. El Merabet, Y. Ruichek, and R. Messoussi, "Local feature extraction based facial emotion recognition: A survey," Int. J. Electr. Comput. Eng., vol. 10, no. 4, pp. 4080-4092, 2020, doi: 10.11591/ijece.v10i4.pp4080-4092.

[17] S. Bagchi, K. G. Tay, A. Huong, and S. K. Debnath, "Image processing and machine learning techniques used in computer-aided detection system for mammogram screening-A review," Int. J. Electr. Comput. Eng., vol. 10, no. 3, pp. 2336-2348, 2020, doi: 10.11591/ijece.v10i3.pp2336-2348.

[18] J. J. Patel and S. K. Hadia, "An enhancement of mammogram images for breast cancer classification using artificial neural networks," IAES Int. J. Artif. Intell., vol. 10, no. 2, pp. 332-345, 2021, doi: 10.11591/ijai.v10.i2.pp332-345.

[19] M. T. Cicerone and C. H. Camp, Potential roles for spectroscopic coherent raman imaging for histopathology and biomedicine. Elsevier Ltd, 2018.

[20] J. Muthuswamy and B. Kanmani, "Optimization based liver contour extraction of abdominal CT images," Int. J. Electr. Comput. Eng., vol. 8, no. 6, pp. 5061-5070, 2018, doi: 10.11591/ijece.v8i6.pp.5061-5070.

[21] J. Park, D. H. Song, and K. B. Kim, "Developing an automatic brachial artery segmentation and bloodstream analysis tool using possibilistic C-means clustering from color Doppler ultrasound images," Int. J. Electr. Comput. Eng., vol. 11, no. 3, pp. 2653-2659, 2021, doi: 10.11591/ijece.v11i3.pp2653-2659.

[22] M. F. Darmawan, A. F. Z. Abidin, S. Kasim, T. Sutikno, and R. Budiarto, "Random forest age estimation model based on length of left hand bone for asian population," Int. J. Electr. Comput. Eng., vol. 10, no. 1, pp. 549-558, 2020, doi: 10.11591/ijece.v10i1.pp549-558.

[23] V. Patanavijit, "Computational scrutiny of image denoising method found on DBAMF under SPN surrounding," Int. J. Electr. Comput. Eng., vol. 10, no. 4, pp. 4109-4117, 2020, doi: 10.11591/ijece.v10i4.pp4109-4117.

[24] N. E. A. Khalid, M. F. Ismail, M. A. A. B. Manaf, A. F. A. Fadzil, and S. Ibrahim, "MRI brain tumor segmentation: A forthright image processing approach," Bull. Electr. Eng. Informatics, vol. 9, no. 3, pp. 1024-1031, 2020, doi: 10.11591/eei.v9i3.2063.

[25] A. AbuBaker and Y. Ghadi, "A novel CAD system to automatically detect cancerous lung nodules using wavelet transform and SVM," Int. J. Electr. Comput. Eng., vol. 10, no. 5, pp. 4745-4751, 2020, doi: 10.11591/ijece.v10i5.pp4745-4751.

[26] R. Pandian, D. N. S. Ravi Kumar, and R. R. Kumar, "Development of algorithm for identification of maligant growth in cancer using artificial neural network," Int. J. Electr. Comput. Eng., vol. 10, no. 6, pp. 5709-5713, 2020, doi: 10.11591/ijece.v10i6.pp5709-5713.

[27] N. Raju, H. B. Anita, and P. Augustine, "Identification of interstitial lung diseases using deep learning," Int. J. Electr. Comput. Eng., vol. 10, no. 6, pp. 6283-6291, 2020, doi: 10.11591/IJECE.V10I6.PP6283-6291.

[28] M. Ed-Dhahraouy, H. Riri, M. Ezzahmouly, A. E. Moutaouakkil, H. Aghoutan, and F. Bourzgui, "Proposition of local automatic algorithm for landmark detection in 3D cephalometry," Bull. Electr. Eng. Informatics, vol. 10, no. 2, pp. 707-715, 2021, doi: 10.11591/eei.v10i2.1827.

[29] M. Y. Kamil, "A deep learning framework to detect Covid-19 disease via chest X-ray and CT scan images," Int. J. Electr. Comput. Eng., vol. 11, no. 1, pp. 844-850, 2021, doi: 10.11591/ijece.v11i1.pp844-850.

[30] S. Salehi Zahabi, H. Rafiei, F. Torabi, A. Salehi, and B. Rezaei, "Evaluation of causes of brain CT scan in patients with minor trauma," Int. J. Surg. Open, vol. 27, pp. 220-224, 2020, doi: 10.1016/j.ijso.2020.11.024.

[31] J. Naàm, J. Harlan, S. Madenda, J. Santony, and C. Suharinto, "Detection of proximal caries at the molar teeth using edge enhancement algorithm," Int. J. Electr. Comput. Eng., vol. 8, no. 5, pp. 3259-3266, 2018, doi: 10.11591/ijece.v8i5.pp.3259-3266.

[32] N. Lokmanulhakim, W. N. A. Rashid, N. H. Hussin, and M. F. Mukhtar, "Experiment study of using parallel plate sensor for the detection of conductive material," Int. J. Electr. Comput. Eng., vol. 9, no. 6, pp. 5628-5635, 2019, doi: 10.11591/ijece.v9i6.pp5628-5635.

[33] N. A. Shairi, N. M. Sanusi, A. Othman, Z. Zakaria, and I. M. Ibrahim, "Performance analysis of ultra-wideband RF switch using discrete PIN diode in SC-79 package for medical application of microwave imaging," Int. J. Electr. Comput. Eng., vol. 9, no. 6, pp. 4668-4674, 2019, doi: 10.11591/ijece.v9i6.pp4668-4674.

[34] I. Assini, A. Badri, A. Sahel, and A. Baghdad, "Hybrid multiple watermarking technique for securing medical images of modalities MRI, CT scan, and X-ray," Int. J. Electr. Comput. Eng., vol. 10, no. 3, pp. 2349-2356, 2020, doi: 10.11591/ijece.v10i3.pp2349-2356.

[35] M. Yumurtaci, G. Gokmen, and T. C. Akinci, "Determining damages in ceramic plates by using discrete wavelet packet transform and support vector machine," Int. J. Electr. Comput. Eng., vol. 10, no. 5, pp. 4759-4769, 2020, doi: 10.11591/ijece.v10i5.pp4759-4769.

[36] C. Jittawiriyanukoon and V. Srisarkun, "Evaluation of color image interpolation based on incompressible navier stokes technique," Bull. Electr. Eng. Informatics, vol. 10, no. 3, pp. 1634-1639, 2021, doi: 10.11591/eei.v10i3.1820.

[37] N. Alrefai and O. Ibrahim, "Deep learning for COVID-19 diagnosis based on chest X-ray images," Int. J. Electr. Comput. Eng., vol. 11, no. 5, pp. 4531-4541, 2021, doi: 10.11591/ijece.v11i5.pp4531-4541. 
[38] J. Shashikala and N. Thangadurai, "Evaluating spatial and frequency domain enhancement techniques on dental images to assist dental implant therapy," Int. J. Electr. Comput. Eng., vol. 11, no. 6, pp. 5019-5033, 2021, doi: 10.11591/ijece.v11i6.pp5019-5033.

[39] A. Ziegler et al., "Digital Three-Dimensional Imaging Techniques Provide New Analytical Pathways for Malacological Research," Am. Malacol. Bull., vol. 36, no. 2, pp. 248-273, 2018, doi: 10.4003/006.036.0205.

[40] H. Hossein, K. M. Ali, M. Hosseini, A. Sarveazad, S. Safari, and M. Yousefifard, "Value of chest computed tomography scan in diagnosis of COVID-19; a systematic review and meta-analysis," Clin. Transl. Imaging, vol. 8, no. 6, pp. 469-481, 2020, doi: 10.1007/s40336-020-00387-9.

[41] A. Clèrigues, S. Valverde, J. Bernal, J. Freixenet, A. Oliver, and X. Lladó, "Acute ischemic stroke lesion core segmentation in CT perfusion images using fully convolutional neural networks," Comput. Biol. Med., vol. 115, no. October, p. 103487, 2019, doi: 10.1016/j.compbiomed.2019.103487.

[42] K. Keklikoglou et al., "Micro-computed tomography for natural history specimens: a handbook of best practice protocols," Eur. J. Taxon., no. 522, pp. 1-55, 2019, doi: 10.5852/ejt.2019.522.

[43] E. Frampas et al., "CT angiography for brain death diagnosis," Am. J. Neuroradiol., vol. 30, no. 8, pp. 1566-1570, 2009, doi: 10.3174/ajnr.A1614.

[44] M. H. Jopri, A. R. Abdullah, T. Sutikno, M. Manap, M. R. A. Ghani, and M. R. Yusoff, "A Critical Review of Time-frequency Distribution Analysis for Detection and Classification of Harmonic Signal in Power Distribution System," Int. J. Electr. Comput. Eng., vol. 8, no. 6, p. 4603, 2018, doi: 10.11591/ijece.v8i6.pp4603-4618.

[45] M. Manap, M. H. Jopri, A. R. Abdullah, R. Karim, M. R. Yusoff, and A. H. Azahar, "A verification of periodogram technique for harmonic source diagnostic analytic by using logistic regression," Telkomnika (Telecommunication Comput. Electron. Control., vol. 17, no. 1, pp. 497-507, 2019, doi: 10.12928/TELKOMNIKA.v17i1.10390.

[46] S. Madhava Prabhu and S. Verma, "Automatic segmentation of plantar thermograms using adaptive C means technique," Int. J. Electr. Comput. Eng., vol. 11, no. 2, pp. 1250-1258, 2021, doi: 10.11591/ijece.v11i2.pp12501258 .

[47] M. Moussa, M. Hamila, and A. Douik, "Face recognition using fractional coefficients and discrete cosine transform tool," Int. J. Electr. Comput. Eng., vol. 11, no. 1, pp. 892-899, 2021, doi: 10.11591/ijece.v11i1.pp892-899.

[48] A. M. Abdu, M. M. Mokji, and U. U. Sheikh, "Machine learning for plant disease detection: An investigative comparison between support vector machine and deep learning," IAES Int. J. Artif. Intell., vol. 9, no. 4, pp. 670683, 2020, doi: 10.11591/ijai.v9.i4.pp670-683.

[49] S. Kuila, N. Dhanda, and S. Joardar, "Feature extraction of electrocardiogram signal using machine learning classification," Int. J. Electr. Comput. Eng., vol. 10, no. 6, pp. 6598-6605, 2020, doi: 10.11591/ijece.v10i6.pp65986605.

[50] M. Y. Kamil, "Computer-aided diagnosis system for breast cancer based on the Gabor filter technique," Int. J. Electr. Comput. Eng., vol. 10, no. 5, pp. 5235-5242, 2020, doi: 10.11591/ijece.v10i5.pp5235-5242.

[51] H. A. Aliyu, M. A. A. Razak, R. Sudirman, and N. Ramli, "A deep learning alexnet model for classification of red blood cells in sickle cell anemia," IAES Int. J. Artif. Intell., vol. 9, no. 2, pp. 221-228, 2020, doi: 10.11591/ijai.v9.i2.pp221-228.

[52] T. Q. Vinh, L. H. Duy, and N. T. Nhan, "Vietnamese handwritten character recognition using convolutional neural network,” IAES Int. J. Artif. Intell., vol. 9, no. 2, pp. 276-283, 2020, doi: 10.11591/ijai.v9.i2.pp276-283.

[53] J. Majidpour and H. Hasanzadeh, "Application of deep learning to enhance the accuracy of intrusion detection in modern computer networks," Bull. Electr. Eng. Informatics, vol. 9, no. 3, pp. 1137-1148, 2020, doi: 10.11591/eei.v9i3.1724.

[54] N. A. Ali, A. R. Syafeeza, A. S. Jaafar, and M. K. M. F. Alif, "Autism spectrum disorder classification on electroencephalogram signal using deep learning algorithm," IAES Int. J. Artif. Intell., vol. 9, no. 1, pp. 91-99, 2020, doi: 10.11591/ijai.v9.i1.pp91-99.

[55] M. F. B. F. Habban, M. Manap, M. H. H. Jopri, A. R. R. Abdullah, M. H. H. Jopri, and T. Sutikno, "An Evaluation of linear time frequency distribution Analysis for VSI switch faults identification," Int. J. Power Electron. Drive Syst., vol. 8, no. 1, p. 1, 2017, doi: 10.11591/ijpeds.v8i1.pp1-9.

[56] A. R. R. Abdullah et al., "An improved detection and classification technique of harmonic signals in power distribution by utilizing spectrogram," Int. J. Electr. Comput. Eng., vol. 7, no. 1, p. 12, 2017, doi: 10.11591/ijece.v7i1.pp12-20.

[57] N. Abidullah, "Analysis of Power Quality Disturbances Using Spectrogram and S-transform," Int. Rev. Electr. Eng., vol. 3, no. June, pp. 611-619, 2014.

[58] I. Q. Abduljaleel and A. H. Khaleel, "Speech signal compression and encryption based on sudoku, fuzzy C-means and threefish cipher," Int. J. Electr. Comput. Eng., vol. 11, no. 6, pp. 5049-5059, 2021, doi: 10.11591/ijece.v11i6.pp5049-5059.

[59] P. Prakash Tunga and V. Singh, "Compression of MRI brain images based on automatic extraction of tumor region,” Int. J. Electr. Comput. Eng., vol. 11, no. 5, pp. 3964-3976, 2021, doi: 10.11591/ijece.v11i5.pp3964-3976.

[60] H. Abdulkarim and M. Z. Al-Faiz, "Online multiclass EEG feature extraction and recognition using modified convolutional neural network method," Int. J. Electr. Comput. Eng., vol. 11, no. 5, pp. 4016-4026, 2021, doi: 10.11591/ijece.v11i5.pp4016-4026.

[61] F. Taher and N. Prakash, "Automatic cerebrovascular segmentation methods-A review," IAES Int. J. Artif. Intell., vol. 10, no. 3, pp. 576-583, 2021, doi: 10.11591/ijai.v10.i3.pp576-583.

[62] A. Al Mamun, P. P. Em, and J. Hossen, "Lane marking detection using simple encode decode deep learning technique: SegNet," Int. J. Electr. Comput. Eng., vol. 11, no. 4, pp. 3032-3039, 2021, doi: 10.11591/ijece.v11i4.pp3032-3039. 
[63] N. Q. Z. Abidin, a R. Abdullah, N. Norddin, a Aman, and K. a Ibrahim, "Leakage Current Analysis on Polymeric Surface Condition using Time-Frequency Distribution," 2012 IEEE Int. Power Eng. Optim. Conf., no. June, pp. 171-175, 2012, doi: 10.1109/PEOCO.2012.6230855.

[64] M. Jopri, A. Abdullah, T. Sutikno, and M. Manap, "A Utilisation of Improved Gabor Transform for Harmonic Signals Detection and Classification Analysis," Int. J., vol. 7, no. 1, pp. 21-28, 2017, doi: 10.11591/ijece.v7i1.pp21-28.

[65] N. M. Kassim, M. Manap, N. A. Ngatiman, and M. R. Yusoff, "Localization of Multiple Harmonic Sources for Inverter Loads Utilizing Periodogram,” J. Teknol., vol. 8, no. 2, pp. 87-91, 2016.

[66] A. R. R. Abdullah, N. S. S. Ahmad, N. Bahari, M. Manap, A. Jidin, and M. H. Jopri, "Short-circuit switches fault analysis of voltage source inverter using spectrogram," Electr. Mach. Syst. (ICEMS), 2013 Int. Conf., pp. 18081813, 2013, doi: 10.1109/icems.2013.6713294.

[67] M. H. Jopri, A. R. Abdullah, M. Manap, M. F. Habban, and T. Sutikno, "An accurate classification method of harmonic signals in power distribution system by utilising S-transform," Telkomnika, vol. 15, no. 1, p. 62, 2017.

[68] A. R. Abdullah, N. A. Abidullah, N. H. Shamsudin, N. H. H. Ahmad, and M. H. Jopri, "Power quality signals classification system using time-frequency distribution," in Applied Mechanics and Materials, 2014, vol. 494, pp. $1889-1894$.

[69] M. Lakshminarayana and M. Sarvagya, "OFCS: Optimized framework of compressive sensing for medical images in bottleneck network condition," Int. J. Electr. Comput. Eng., vol. 8, no. 5, pp. 2829-2838, 2018, doi: 10.11591/ijece.v8i5.pp.2829-2838.

[70] H. Ham, J. Wesley, and Hendra, "Computer vision based 3D reconstruction: A review," Int. J. Electr. Comput. Eng., vol. 9, no. 4, pp. 2394-2402, 2019, doi: 10.11591/ijece.v9i4.pp2394-2402.

[71] S. A. Hameed, A. Haddad, M. H. Habaebi, and A. Nirabi, "Dermatological diagnosis by mobile application," Bull. Electr. Eng. Informatics, vol. 8, no. 3, pp. 847-854, 2019, doi: 10.11591/eei.v8i3.1502.

[72] J. O. Pinzón-Arenas, R. Jiménez-Moreno, and C. G. Pachón-Suescún, "ResSeg: Residual encoder-decoder convolutional neural network for food segmentation," Int. J. Electr. Comput. Eng., vol. 10, no. 1, pp. 1017-1026, 2020, doi: 10.11591/ijece.v10i1.pp1017-1026.

[73] M. Mahmood, B. Al-Khateeb, and W. M. Alwash, "A review on neural networks approach on classifying cancers," IAES Int. J. Artif. Intell., vol. 9, no. 2, pp. 317-326, 2020, doi: 10.11591/ijai.v9.i2.pp317-326.

[74] I. S. Al-Mejibli, J. K. Alwan, and D. H. Abd, "The effect of gamma value on support vector machine performance with different kernels," Int. J. Electr. Comput. Eng., vol. 10, no. 5, pp. 5497-5506, 2020, doi: 10.11591/ijece.v10i5.pp5497-5506.

[75] O. AlShorman, B. AlShorman, and F. Alkahtani, "A review of wearable sensors based monitoring with daily physical activity to manage type 2 diabetes," Int. J. Electr. Comput. Eng., vol. 11, no. 1, pp. 646-653, 2021, doi: 10.11591/ijece.v11i1.pp646-653.

[76] K. Sharma et al., "Automatic Segmentation of Kidneys using Deep Learning for Total Kidney Volume Quantification in Autosomal Dominant Polycystic Kidney Disease," Sci. Rep., vol. 7, no. 1, pp. 1-10, 2017, doi: 10.1038/s41598-017-01779-0.

[77] T. N. S. Tengku Zawawi, A. R. Abdullah, M. H. Jopri, T. Sutikno, N. M. Saad, and R. Sudirman, "A review of electromyography signal analysis techniques for musculoskeletal disorders," Indones. J. Electr. Eng. Comput. Sci., vol. 11, no. 3, pp. 1136-1146, 2018, doi: 10.11591/ijeecs.v11.i3.pp1136-1146.

[78] I. Aranguren, A. Valdivia, B. Morales-Castañeda, D. Oliva, M. Abd Elaziz, and M. Perez-Cisneros, "Improving the segmentation of magnetic resonance brain images using the LSHADE optimization algorithm," Biomed. Signal Process. Control, vol. 64, no. October 2020, 2021, doi: 10.1016/j.bspc.2020.102259.

[79] K. B. Kim and D. H. Song, "Fully automatic segmentation of intima/adventitia of the vessel using Bezier curve from intravascular ultrasound," Int. J. Electr. Comput. Eng., vol. 11, no. 3, pp. 2640-2646, 2021, doi: 10.11591/ijece.v11i3.pp2640-2646.

[80] H. A. Ghani et al., "Advances in lane marking detection algorithms for all-weather conditions," Int. J. Electr. Comput. Eng., vol. 11, no. 4, pp. 3365-3373, 2021, doi: 10.11591/ijece.v11i4.pp3365-3373.

[81] B. C. C. Meng, D. S. A. Damit, and N. S. Damanhuri, "Comparative studies of multiscale edge detection using different edge detectors for mri thigh," Bull. Electr. Eng. Informatics, vol. 10, no. 4, pp. 1979-1986, 2021, doi: 10.11591/eei.v10i4.2220.

[82] K. B. Kim, D. H. Song, and S.-S. Yun, "Automatic segmentation of wrist bone fracture area by K-means pixel clustering from X-ray image," Int. J. Electr. Comput. Eng., vol. 9, no. 6, pp. 5205-5210, 2019, doi: 10.11591/ijece.v9i6.pp5205-5210.

[83] A. M. Khairuddin, K. N. F. Ku Azir, and P. Eh Kan, "A general framework for improving electrocardiography monitoring system with machine learning," Bull. Electr. Eng. Informatics, vol. 8, no. 1, pp. 261-268, 2019, doi: 10.11591/eei.v8i1.1400.

[84] S. Saeed and A. Abdullah, "Recognition of brain cancer and cerebrospinal fluid due to the usage of different MRI image by utilizing support vector machine," Bull. Electr. Eng. Informatics, vol. 9, no. 2, pp. 619-625, 2020, doi: 10.11591/eei.v9i2.1869.

[85] T. Dewi, P. Risma, and Y. Oktarina, "Fruit sorting robot based on color and size for an agricultural product packaging system," Bull. Electr. Eng. Informatics, vol. 9, no. 4, pp. 1438-1445, 2020, doi: 10.11591/eei.v9i4.2353.

[86] S. Harish and G. F. A. Ahaimned, "An optimized approach for extensive segmentation and classification of brain MRI," Int. J. Electr. Comput. Eng., vol. 10, no. 3, pp. 2392-2401, 2020, doi: 10.11591/ijece.v10i3.pp2392-2401.

[87] H. J. Abd, A. S. Abdullah, and M. S. S. Alkafaji, "A new swarm intelligence information technique for improving 
information balancedness on the skin lesions segmentation,” Int. J. Electr. Comput. Eng., vol. 10, no. 6, pp. $5703-$ 5708, 2020, doi: 10.11591/ijece.v10i6.pp5703-5708.

[88] N. A. Al-Azzawi, "Microscopy images segmentation algorithm based on shearlet neural network," Bull. Electr. Eng. Informatics, vol. 10, no. 2, pp. 724-731, 2021, doi: 10.11591/eei.v10i2.2743.

[89] J. Ravikumar and P. Ramakanth Kumar, "Machine learning model for clinical named entity recognition," Int. J. Electr. Comput. Eng., vol. 11, no. 2, pp. 1689-1696, 2021, doi: 10.11591/ijece.v11i2.pp1689-1696.

[90] A. H. Ali, S. A. Al-Hadi, M. R. Naeemah, and A. N. Mazher, "Classification of Brain Lesion using K- Nearest Neighbor technique and Texture Analysis," J. Phys. Conf. Ser., vol. 1178, no. 1, 2019, doi: 10.1088/17426596/1178/1/012018.

[91] T. Badriyah, N. Sakinah, I. Syarif, and D. R. Syarif, "Segmentation stroke objects based on CT scan image using thresholding method," Proc. - 2019 1st Int. Conf. Smart Technol. Urban Dev. STUD 2019, pp. 61-65, 2019, doi: 10.1109/STUD49732.2019.9018825.

[92] F. Flottmann et al., "CT-perfusion stroke imaging: A threshold free probabilistic approach to predict infarct volume compared to traditional ischemic thresholds," Sci. Rep., vol. 7, no. 1, pp. 1-10, 2017, doi: 10.1038/s41598-01706882-w.

[93] I. Kumar, C. Bhatt, and K. U. Singh, "Entropy based automatic unsupervised brain intracranial hemorrhage segmentation using CT images," J. King Saud Univ. - Comput. Inf. Sci., no. xxxx, pp. 1-12, 2020, doi: 10.1016/j.jksuci.2020.01.003.

[94] H. S. Bhadauria and M. L. Dewal, "Intracranial hemorrhage detection using spatial fuzzy c-mean and region-based active contour on brain CT imaging," Signal, Image Video Process., vol. 8, no. 2, pp. 357-364, 2014, doi: 10.1007/s11760-012-0298-0.

[95] Gautam, Anjali, Debanjan Sadhya, and Balasubramanian Raman. "A Modified FCM-Based Brain Lesion Segmentation Scheme for Medical Images." In Proceedings of 3rd International Conference on Computer Vision and Image Processing, pp. 149-159. Springer, Singapore, 2020.

[96] E. S. Biratu, F. Schwenker, T. G. Debelee, S. R. Kebede, W. G. Negera, and H. T. Molla, "Enhanced Region Growing for Brain Tumor MR Image Segmentation," J. Imaging, vol. 7, no. 2, p. 22, 2021, doi: 10.3390/jimaging 7020022 .

[97] A. H. Ali, S. I. Abdulsalam, and I. S. Nema, "Detection and Segmentation of Hemorrhage Stroke using Textural Analysis on Brain CT Im ages," Int. J. Soft Comput. Eng., vol. 5, no. 1, pp. 11-14, 2015.

[98] M. Matešin, L. Sven, and D. Petravić, "A rule-based approach to stroke lesion analysis from CT brain images," Int. Symp. Image Signal Process. Anal. ISPA, vol. 2001-Janua, pp. 219-223, 2001, doi: 10.1109/ISPA.2001.938631.

[99] Gupta, Nancy, and Ajay Mittal. "Brain ischemic stroke segmentation: a survey." Journal of Multi Disciplinary Engineering Technologies 8, no. 1 (2014): 1.

[100] S. Saini and V. Banga, "A Review: Haemorrhage Intracranial Segmentation in CT Brain Images," Int. J. Eng. Res. Technol., vol. 2, no. 10, pp. 2022-2026, 2013, [Online]. Available: http://www.ijert.org/browse/volume-22013/october-2013-edition?download=5789:a-review-haemorrhage-intracranial-segmentation-in-ct-brainimages\&start $=290$.

[101] M. Ajam, H. Kanaan, M. Ayache, and L. El Khansa, "Segmentation of CT Brain Stroke Image using Marker Controlled Watershed," Int. Conf. Adv. Biomed. Eng. ICABME, vol. 2019-Octob, pp. 2019-2022, 2019, doi: 10.1109/ICABME47164.2019.8940346.

[102] E. de S. Rebouças, R. C. P. Marques, A. M. Braga, S. A. F. Oliveira, V. H. C. de Albuquerque, and P. P. Rebouças Filho, "New level set approach based on Parzen estimation for stroke segmentation in skull CT images," Soft Comput., vol. 23, no. 19, pp. 9265-9286, 2019, doi: 10.1007/s00500-018-3491-4.

[103] M. Ajam, H. Kanaan, L. El Khansa, and M. Ayache, "Identification of ischemic stroke by marker controlled watershed segmentation and fearture extraction," Int. Arab J. Inf. Technol., vol. 17, no. 4 Special Issue, pp. 671676, 2020, doi: 10.34028/iajit/17/4A/12.

[104] B. Arasan, S. K. B, S. S. P, and T. Veena, "An Automated Hemorrhage Detection System using Watershed Segmentation and Active Contour," vol. 3, no. 1, pp. 1-6, 2020.

[105] Nivedhitha P, and Sankar S., "Hemorrhage Detection System Using Watershed Segmentation," International Journal of Applied Engineering Research, vol. 14, no. 5, pp. 45-51, 2019 (Special Issue).

[106] R. Pitchai, P. Supraja, A. H. Victoria, and M. Madhavi, "Brain Tumor Segmentation Using Deep Learning and Fuzzy K-Means Clustering for Magnetic Resonance Images,” Neural Process. Lett., 2020, doi: 10.1007/s11063020-10326-4.

[107] R. Vankayalapati, K. B. Ghutugade, R. Vannapuram, and B. P. S. Prasanna, "K-means algorithm for clustering of learners performance levels using machine learning techniques," Rev. d'Intelligence Artif., vol. 35, no. 1, pp. 99104, 2021, doi: 10.18280/ria.350112.

[108] Pallavi Purohit and Ritesh Joshi, "A New Efficient Approach towards k-means Clustering Algorithm," Int. J. Comput. Appl., vol. 65, no. 11, pp. 7-10, 2013.

[109] T. H. Lee, M. F. A. Fauzi, and R. Komiya, "Segmentation of CT brain images using K-means and EM clustering," Proc. - Comput. Graph. Imaging Vis. Mod. Tech. Appl. CGIV, pp. 339-344, 2008, doi: 10.1109/CGIV.2008.17.

[110] N. Hema Rajini and R. Bhavani, "Computer aided detection of ischemic stroke using segmentation and texture features," Meas. J. Int. Meas. Confed., vol. 46, no. 6, pp. 1865-1874, 2013, doi: 10.1016/j.measurement.2013.01.010.

[111] A. Irimia, A. S. Maher, K. A. Rostowsky, N. F. Chowdhury, D. H. Hwang, and E. M. Law, "Brain segmentation from computed tomography of healthy aging and geriatric concussion at variable spatial resolutions," Front. Neuroinform., vol. 13, no. March, pp. 1-12, 2019, doi: 10.3389/fninf.2019.00009. 
[112] L. L. Cui and H. Zhang, "Study on threshold segmentation of multi-resolution 3D human brain CT image," J. Innov. Opt. Health Sci., vol. 11, no. 6, pp. 1-9, 2018, doi: 10.1142/S1793545818500372.

[113] X. Qian, Y. Lin, Y. Zhao, X. Yue, B. Lu, and J. Wang, "Objective Ventricle Segmentation in Brain CT with Ischemic Stroke Based on Anatomical Knowledge,” Biomed Res. Int., vol. 2017, 2017, doi: 10.1155/2017/8690892.

[114] P. Singh, V. Khanna, and M. Kamal, "Hemorrhage segmentation by fuzzy c-mean with Modified Level Set on CT imaging," 2018 5th Int. Conf. Signal Process. Integr. Networks, SPIN 2018, no. 1, pp. 550-555, 2018, doi: 10.1109/SPIN.2018.8474166.

[115] B. Suneetha and A. Jhansi Rani, Brain tumor detection in MR imaging using DW-MTM filter and region-growing segmentation approach, vol. 815. Springer Singapore, 2019.

[116] W. Zhu and Y. Shen, “A Region Growing Segmentation Approach for MRI Brain Image Processing," Proc. Int. Conf. Anti-Counterfeiting, Secur. Identification, ASID, vol. 2019-Octob, pp. 188-191, 2019, doi: 10.1109/ICASID.2019.8925066.

[117] B. Hachemi et al., "Fully automatic multisegmentation approach for magnetic resonance imaging brain tumor detection using improved region-growing and quasi-Monte Carlo-expectation maximization algorithm," Int. J. Imaging Syst. Technol., vol. 30, no. 1, pp. 104-111, 2020, doi: 10.1002/ima.22376.

[118] G. M. Tarhini and R. Shbib, "Detection of Brain Tumor in MRI Images Using Watershed and Threshold-Based Segmentation," Int. J. Signal Process. Syst., vol. 8, no. 1, pp. 19-25, 2020, doi: 10.18178/ijsps.8.1.19-25.

[119] S. Lou, L. Pagani, W. Zeng, X. Jiang, and P. J. Scott, "Watershed segmentation of topographical features on freeform surfaces and its application to additively manufactured surfaces," Precis. Eng., vol. 63, no. August 2019, pp. 177-186, 2020, doi: 10.1016/j.precisioneng.2020.02.005.

[120] A. M. A. A. Abang Isa et al., "Pseudo-colour with K-means Clustering Algorithm for Acute Ischemic Stroke Lesion Segmentation in Brain MRI," Pertanika J. Sci. Technol., vol. 29, no. 2, pp. 743-757, 2021, doi: 10.47836/pjst.29.2.03.

[121] T. C. Hakyemez, A. Bozanta, and M. Coşkun, "K-Means vs . Fuzzy C-Means : A Comparative Analysis of Two Popular Clustering Techniques on the Featured Mobile Applications Benchmark," 5th Int. Manag. Inf. Syst. Conf., 2018.

[122] M. S. Alam et al., "Automatic human brain tumor detection in mri image using template-based $\mathrm{k}$ means and improved fuzzy c means clustering algorithm," Big Data Cogn. Comput., vol. 3, no. 2, pp. 1-18, 2019, doi: 10.3390/bdcc3020027.

\section{BIOGRAPHIES OF AUTHORS}

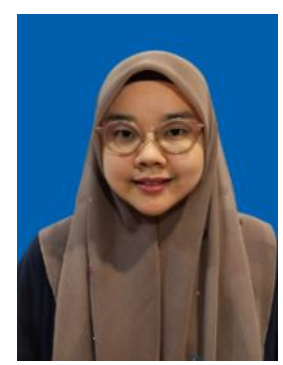

Nur Hasanah Ali obtained the BEng (Hons) Electronics majoring in Telecommunications from the Multimedia Univeristy, in May 2007. She then received her Master of Electronic Engineering (Tele-communication System) in 2012 from Universiti Teknikal Malaysia Melaka (UTeM). She is currently a Lecturer at the Faculty of Engineering and Technology, Multimedia University in Malaysia. Her research interests cover the Digital Image Processing, Artificial Intelligence and Medical Imaging. She registered with Board of Engineer Malaysia (BEM).

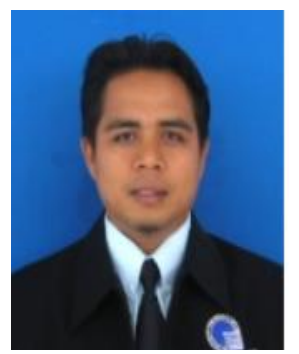

Abdul Rahim Abdullah received his B. Eng.in Electrical Engineering (2001), Masters Degree in Electrical Engineering (2004) and PhD in Power Electronic and Digital Signal Processing (2011) from Universiti Teknologi Malaysia (UTM). He is currrently an Associate Professor in the Department of Power Electronic \& Drive, Faculty of Electrical Engineering, Universiti Teknikal Malaysia Melaka (UTeM) and Head of Advance Digital Signal Processing (ADSP) Lab. His field of specialization includes, Advance Digital Signal Processing, Rehabilitation Engineering, Assistive Technology and Power Electronics and Drive. He registered with Board of Engineer Malaysia (BEM), Malaysia Board of Technologist (MBOT), Institute of Engineer Malaysia (IEM), and Members of International Association of Engineers (IAENG).

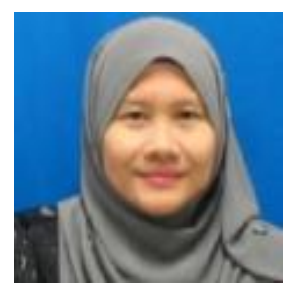

Norhashimah Mohd Saad is a senior lecturer at Department of Electronic and Computer Engineering Technology, Faculty of Electrical and Electronic Engineering Technology, Universiti Teknikal Malaysia Melaka (UTeM). She received her B. Eng in Medical Electronics (2001), Master Eng. In Telecommunication (2004) and PhD in Digital Image Processing (2015) from Universiti Teknologi Malaysia (UTM). Her research area involved Digital Image and Signal Processing, Computer Vision and Medical Imaging. She registered with Board of Engineer Malaysia (BEM), Malaysia Board of Technologist (MBOT), Institute for Electrical and Electronics Engineer (IEEE), Signal Processing Society (SPS), IEEE Engineering in Medical and Biology Society (EMBS) and International Association of Engineers (IAENG).

Int J Artif Intell, Vol. 10, No. 4, December 2021: 1048 - 1059 

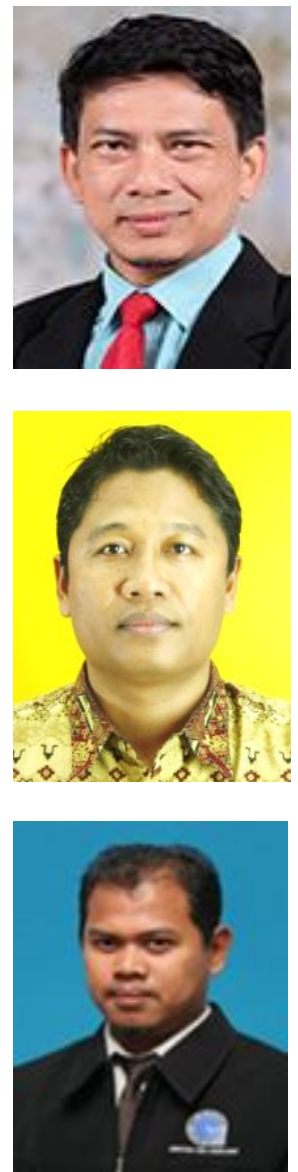

Ahmad Sobri Muda received the medical degree in medicine from UKM, followed by specialist training in radiology from USM. He pursued his sub-speciality training in interventional Neuroradiology with the Foundation Rothschild Hospital, Paris. He was an interventional Neuroradiologist Consultant. He is currently a Professor of Radiology with the Imaging Department, Faculty of Medicine and Health Sciences, Universiti Putra Malaysia, Malaysia. His research interest includes neurointervention, neuroradiology and interventional radiology. He is a member of the Malaysian Society of Neuroscience and the Ex-Chairman for Malaysian Neuroradiology Section. He is also one of the Founding Member of Endovascular and Interventional Radiology UKM Malaysian Society of Interventional Radiology and teaching workshop in neurointervention.

Tole Sutikno is a Lecturer in Electrical Engineering Department at the Universitad Ahmad Dahlan (UAD), Yogyakarta, Indonesia. He received his B.Eng., M.Eng. and Ph.D. degrees in Electrical Engineering from Universitas Diponegoro, Universitas Gadjah Mada and Universiti Teknologi Malaysia, in 1999, 2004 and 2016, respectively. He has been an Associate Professor in UAD, Yogyakarta, Indonesia since 2008. He is currently an Editor-in-Chief of the TELKOMNIKA since 2005, and the Head of the Embedded Systems and Power Electronics Research Group since 2016. His research interests include the field of industrial applications, industrial electronics, industrial informatics, power electronics, motor drives, renewable energy, FPGA applications, embedded system, image processing, artificial intelligence, intelligent control, digital design and digital library.

Mohd Hatta Jopri was born in Johor, Malaysia on 1978. He received his B.Eng from Universiti Teknologi Malaysia (UTM) in 2000, Msc. in Electrical Power Engineering from Rheinisch-Westfälische Technische Hochschule Aachen (RWTH), Germany, and PhD from Universiti Teknikal Malaysia Melaka (UTeM), respectively. Since 2005, he is an academia and research staff at UTeM. He registered with Malaysia Board of Technologist (MBOT), and a member of International Association of Engineers (IAENG). His research interests include power electronics and drive, power quality analysis, signal processing, machine learning and data science. 